\title{
The Methodological Consistency of Master's of Education Dissertations at Eduardo Mondlane University (2013 - 2018)
}

\author{
Octavio Zimbico and Arsenia Manuel
}

\begin{abstract}
This study examined the methodological consistency of Master of Education dissertations defended at Eduardo Mondlane University (EMU) from 2013 to 2018 using the typology of educational research proposed by Postlethwaite (2005), Norman et al. (2002), and Creswell (2012). The qualitative, comparative study employed a grounded theory design. Data were gathered from a purposive sample of 33 dissertations, available on the university's Open Institutional Repository. Coding and anonymous analysis were performed of the dissertations' title, research methodology, and findings. The findings reveal that a large number of these dissertations are not methodologically consistent and thus do not lay the foundation for further research and other interventions for school improvement. They thus point to the need to improve the quality of supervision and research in postgraduate studies in Education at EMU.
\end{abstract}

Key words: EMU, Master's dissertations, educational research, methodological consistency, supervision

Cette étude a examiné la cohérence méthodologique des mémoires de maîtrise en éducation soutenus à l'Université Eduardo Mondlane (EMU) de 2013 à 2018 en utilisant la typologie de la recherche en éducation proposée par Postlethwaite (2005), Norman et al. (2002) et Creswell (2012). L'étude qualitative et comparative a utilisé une conception théorique ancrée. Les données ont été recueillies à partir d'un échantillon intentionnel de 33 thèses, disponibles sur le référentiel institutionnel ouvert de

ABOUt THE AUthors: octavio zimbico, Eduardo Mondlane University, Mozambique. Email: o.zimbico@gmail.com and ARSENIA MANUel, Eduardo Mondlane University, Mozambique. 
l'université. Le codage et l'analyse anonyme ont été effectués sur le titre des thèses, la méthodologie de recherche et les résultats. Les résultats révèlent qu'un grand nombre de ces thèses ne sont pas cohérents sur le plan méthodologique et ne jettent donc pas les bases d'autres recherches et d'autres interventions pour l'amélioration de l'école. Ils soulignent ainsi la nécessité d'améliorer la qualité de l'encadrement et de la recherche dans les études de troisième cycle en éducation à l'UEM.

Mots clés: EMU, mémoires de master, recherche pédagogique, cohérence méthodologique, encadrement.

\section{Introduction}

The international literature suggests that the characteristics and trends of education have significant implications for training and research. Maynard et al. (2012) state that the lack of applied research by doctoral candidates reflects a deficit in research capacity within university schools. In order to engage in relevant and applied research, faculty members need to be skilled in advanced research methodologies.

Furthermore, schools need to be committed to conducting applied research, building community-university partnerships, and securing funding to provide opportunities for students to engage in applied research. Maynard et al. (20I2) recommend building a research culture and infrastructure within schools to facilitate the training and professionalisation of candidates to engage in practice-relevant research, build the knowledge base and advance the profession's efforts to build research capacity after they graduate. On the other hand, Mohajan (2018, p. I) asserts that "every research must involve an explicit, disciplined, systematic (planned, ordered, and public) approach to find out most appropriate results".

According to Langa (20I8), Higher Education (HE) in Mozambique is in an incipient stage as it grows to become a more complex social institution. However, "it is not possible to establish whether this complexity has already ignited a functioning field of HE research" (Langa, 2018, p. 58). Mário et al. (2003, p. 59) recommended that Mozambican HE institutions should promote "a closer link between teaching and research through applied research" to improve the relevance of their curricula. There is a strong link between Mozambican HE and Eduardo Mondlane University (EMU). The university was established in I962 in what was then Lourenço Marques (now Maputo), the capital of Portugal's overseas province of Mozambique. Initially known as Mozambique General University Studies; in I968 it became the University of Lourenço Marques. Following Mozambique's independence in I975, the university was renamed in honour of Mozambique Liberation Front leader, Eduardo Mondlane, in I976 (Mário et al., 2003; Langa, 2018).
Eduardo Mondlane University's vision is to be a national and international reference in knowledge production and innovation in Education and Psychologyr (EMU, 20I3). The Master's degree in Education is expected to "train professionals with skills of research, teaching, and management"; enabling them to act at "public and private institutions, including universities, primary and secondary schools" (EMU, 20I8, p. 6). Given that "research" means orderly investigation of a subject to add to knowledge, it implies that the subject matter is already known but, for some reason, needs to be studied again (Postlethwaite, 2005). Educational research plays "the role of providing attested information to improve the quality of decision-making for educational policy" (Livingstone, 2005, p. I).

From its inception, HE in Mozambique was always public, in line with the socialist ideology of its first post-independence governments (Langa and Zavale, 20I5). Following the liberalisation of the economy, private HE emerged in the mid-I g9os, leading "to an increase in the number and type of HE institution suppliers, which inevitably created an environment of competition among the different institutions" (p. 89). Within this environment, student numbers increased, putting the system under pressure and posing the risk of a drop in the quality of educational offerings.

Ever-increasing human needs and technological advances mean that passive knowledge transmission is not sufficient and that students should be taught in a manner that enables them to develop their research skills (Ali and Abbas, 2018).

The Study Group on Educational Law and Policy at EMU that brings together lecturers and researchers undertaking studies on the right to education (i.e., access, financing, and management) at different levels (primary, secondary, and higher) 2 has engaged in much discussion on the role of educational research. As research expectations of universities increase, competitiveness also increases (Robles, 20I6) and faculty members are thus under pressure to produce research in their fields.

One of the key issues raised in the education literature is the extent to which research should be chiefly directed towards school improvement, in general, and facilitating effective classroom practice, in particular. Some scholars, such as Carnine (2000), believe that, like medicine, education should be an "evidenced-based" field, in which findings are used in line with the contexts in which different schools operate. This concurs with Hempenstall (2006), who interpreted educational research as "the art of searching in education" rather than a "science" per se (Postlethwaite, 2005). Our study examined the methodological consistency of the Master

Available online at: https:/www.uem.mz/index.php/faculdades-e-escolas/faculdades/faculdade-deeducacao.

2 More details on this group are available at: http://www.faced.uem.mz/index.php/grupos-de-pesquisa. 
of Education dissertations defended at EMU from 2013 to 2018 in light of the methodological trustworthiness of educational research proposed by Postlethwaite (2005), Norman et al. (2002), and Creswell (20I2).

\section{Problem statement}

Funding challenges faced by "Sub-Saharan African universities are likely to impact on the nature of and motive for undertaking academic research, resulting in different orientations from those of Western universities" (Kaweesi et al., 20I9, p. 3). In Mozambique, EMU promotes excellence "based on the postulates of quality and trustworthiness of production of knowledge through research" (EMU, 2007, p. 3). However, it is reported that research conducted at this institution suffers from "weaknesses in several aspects of research management, such as quality of research output" (p. I). The type of research will dictate the research methodologies that should underpin the methods. Regardless of the methodology, data collection techniques must fit with the study's objectives. Moreover, "it is important that the technique used to collect data is adequate to provide the information required to accomplish the overall goals of the study" (Opoku et al., 20I6, p. 32). As such, research-oriented teaching is an emerging trend in HE and is widely used in developed countries (Ali and Abbas, 20I9).

Training at EMU should be based on principles and methods that enable students to develop an academic attitude towards reflection, analysis, and critical thinking (EMU, 20I3). As noted by Langa (20I4, p. 370), "at all levels of Mozambique predominates a more experiential knowledge of HE and there is a shortage of a scientific-based knowledge". Due to the shift from traditional methods to research-oriented teaching, changes are occurring in teaching styles. Our study was motivated by the fact that no research has been conducted on the scientific trustworthiness of Master's dissertations in Education at EMU. There is thus a need to verify the methodological consistency of these dissertations. The problem raised the following question:

How consistent are the Master's dissertations defended at EMU from 2013 to 20183 in light of the methodological trustworthiness of educational research proposed by Postlethwaite (2005), Norman et al. (2002), and Creswell (20I2)?

\section{Operational definition}

According to Newman and Covrig (20I7, p. 79), "there is no perfect research, but building consistency into a research plan and reflecting on the alignment between the title, purpose, problem, and research questions will greatly improve the quality of the research". When consistency is achieved, contradictory conclusions cannot be derived from the research. However,

3 In 2013 the EMU launched a new vision of being "a research-oriented university". if "there is no coherence and consistency within the approach, the processes cannot be followed and theory generation is impossible" (Holloway and Todres, 2005, p. 98). This "does not mean that the same result would necessarily be found in other contexts but that, given the same data, other researchers would find similar patterns" (Hammarberg et al., 20I6, p. 500). Therefore, consistency refers to the extent "to which repeated administration of a measure will provide the same data or the extent to which a measure administered once, but by different people, produces equivalent results" (Krefting, I99I, p. 2I6).

Each approach has to demonstrate consistency with its foundations and will reflect them in data collection, analysis, and knowledge claims. If consistency is achieved, "the whole thing 'hangs together' as coherent; that is, the kind of knowledge generated in the results or presentation section does what it said it would do under the aims of the project" (Holloway and Todres, 2005, p. 93). Thus, an independent researcher should arrive at similar findings (Noble and Smith, 20I5).

According to Brown (20I7, p. 23), "consistency in research design falls in three categories: quantitative reliability, qualitative dependability, and mixed methods research dependability".

Quantitative reliability is the degree to which the results of observations are consistent in a study, but the study as a whole is also consistent internally and externally. Two primary strategies should be used to enhance the reliability of a quantitative study (Brown, 20I7). First, the reliability of observations can be enhanced by calculating reliability estimates for measures or agreement estimates for ratings and coding. Second, the reliability of the results of the study as a whole can be enhanced internally (by carefully monitoring and controlling issues that might contribute to inconsistency) and externally (by inspecting the statistical tests that are run to determine the degree to which the results would be likely to be stable if the study were replicated).

According to Brown (20I7), qualitative dependability involves enhancing the consistency of observations and the effects of changing conditions in the study by using one or more of three strategies. The first is method triangulation, which involves multiple data gathering techniques. The second strategy is time triangulation, with data gathered multiple times and the third is investigator triangulation, which means that multiple investigators are involved in the study.

\section{Objective of the study}

The study's objective was to examine the methodological consistency of the Master's in Education dissertations defended at EMU from 2013 to 2018 , in light of the methodological trustworthiness of educational research proposed by Postlethwaite (2005), Norman et al. (2002), and Creswell (20I2). 


\section{Method}

This was a qualitative (grounded theory design) and comparative study (Tie et al., 20I9). Grounded theory design is a systematic, qualitative procedure that researchers use to generate a general conception (grounded in the views of participants, called a grounded theory) that explains a process, action, or interaction among people (Creswell, 20I2). The procedures to develop this theory include collecting data (from dissertations), developing and relating categories (or themes) of information, and composing a figure or visual model that portrays the general explanation.

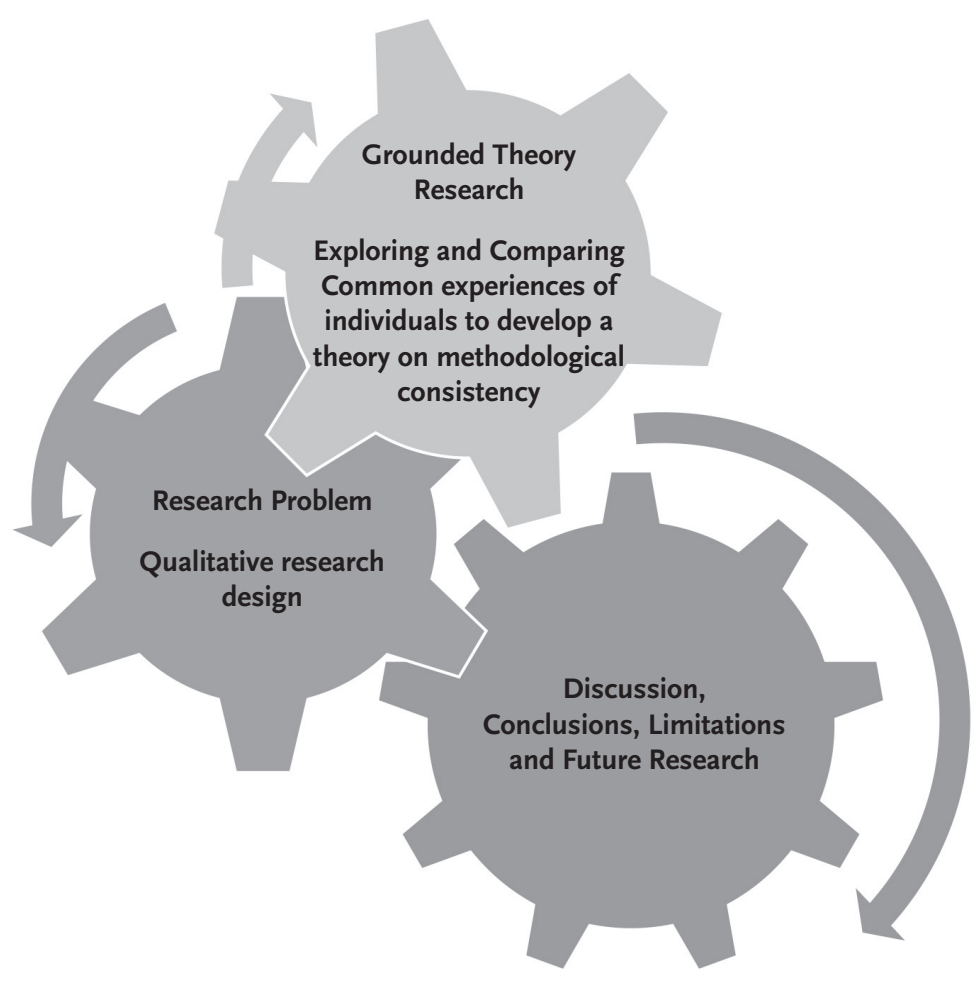

Figure 1. Visual model of the research design and general explanation

In terms of comparisons, we selected particular units and aspects (such as the research title, educational research methodology, and findings) rather than others (why and how a given phenomenon is analysed in the dissertations). As a construction, "comparison thus helps to create an ordered perception of this reality, i.e., an organized way to see it in one rather than in many other alternative ways" (Azarian, 20II, p. I23). Comparisons were, therefore, based on checking the methodology of the dissertations under the types of educational research proposed by Postlethwaite (2005), which enables identification of the type of research and how it should be conducted. Comparisons emerged as the data analysis proceeded as in grounded theory, through relating categories of information that allowed propositions (Creswell, 20I2).

Population and sampling strategy

Electronic versions of the dissertations were accessed on EMU's institutional repository. Only dissertations that meet specific quality requirements are made available on the repository. From a population of 90 dissertations defended from 2013 to 2018 (see Table I), a purposive sample of 33, available on the repository, was selected, "based on the assumption that these elements represent a 'typical sample' from the appropriate target population" (Ross, 2005, p. 7).

Table 1: Students enrolled and graduated by cohort

\begin{tabular}{|c|c|c|c|c|c|c|c|c|c|c|c|c|c|}
\hline \multirow[t]{2}{*}{ Year } & \multicolumn{4}{|c|}{ Registered } & \multicolumn{4}{|c|}{ Graduates (True cohort) } & \multicolumn{4}{|c|}{ Graduates (False cohort) } & \multirow{2}{*}{$\begin{array}{l}\text { Total of } \\
\text { graduates }\end{array}$} \\
\hline & EAM & ENSM & $A E$ & CID & EAM & ENSM & $A E$ & CID & EAM & ENSM & $\mathrm{AE}$ & CID & \\
\hline 2009 & 6 & 5 & 0 & 6 & 0 & 0 & $\mathrm{o}$ & 0 & 0 & o & $\mathrm{o}$ & 0 & o \\
\hline 2010 & o & 11 & 16 & 13 & o & o & o & o & o & o & $\circ$ & o & o \\
\hline 2011 & 16 & 6 & o & 10 & 2 & o & o & o & 5 & 2 & 4 & 5 & 18 \\
\hline 2012 & 20 & 8 & 7 & 17 & $\circ$ & $\circ$ & 1 & $\circ$ & 2 & 1 & $\circ$ & 1 & 5 \\
\hline 2013 & 15 & o & 13 & 13 & $\circ$ & $\circ$ & $\circ$ & $\circ$ & 3 & 1 & 3 & 2 & 9 \\
\hline 2014 & 19 & 7 & 19 & 6 & 8 & $\circ$ & 0 & 2 & 0 & 2 & 1 & $\circ$ & 13 \\
\hline 2015 & 17 & o & o & 7 & 1 & 0 & o & 1 & 3 & 1 & 2 & 2 & 10 \\
\hline 2016 & 13 & 0 & 6 & 8 & 0 & 0 & o & 0 & 2 & 1 & 5 & 5 & 13 \\
\hline 2017 & o & 0 & 0 & 0 & 0 & 0 & 0 & 0 & 6 & 0 & 2 & 4 & 12 \\
\hline 2018 & 0 & 0 & 0 & 0 & 0 & 0 & 0 & 0 & 4 & 0 & 0 & 6 & 10 \\
\hline Total & 106 & 37 & 61 & 80 & 11 & 0 & 1 & 3 & 25 & 8 & 17 & 24 & 90 \\
\hline
\end{tabular}

EAM: Educational Administration and Managemen

ENSM: Education in Natural Sciences and Mathematics

AE: Adult Education

CID: Curriculum and Instructional Development

Source: University Librarian Services (2020)

With permission from the Library Services, these dissertations were downloaded and their titles, objectives, methods, and conclusions were analysed.

\section{Material}

Data collection commenced with a systematic literature review on educational research and identification of the 33 dissertations. This was followed by construction and validation of the analytic model based on the descrip- 
tion of eight types of educational research proposed by Postlethwaite (2005). This typology (i.e., historical, descriptive, correlational, causal, experimental, case study, ethnographic, and research and development) was validated through "investigator triangulation" (Norman et al., 2002; Creswell, 20I2). The eight types of educational research were drawn from Educational Research: some basic concepts and terminology, jointly produced by International Institute for Educational Planning (IIEP) and the Southern and Eastern Africa Consortium for Monitoring Educational Quality (SACMEQ). These types were also adopted by the College of Social Sciences and International Studies of Exeter University in the United Kingdom, and by the University of Sao Paulo in Brazil. This was deemed an appropriate methodological lens to understand educational research from a Southern African perspective.

\section{Data analysis}

Data analysis was based on a comparison of each type of research with the corresponding description and definition (Norman et al., 2002; Postlethwaite, 2005; Creswell, 2012). We adopted a two-stage comparison to firstly, verify the types of educational research; and secondly, to determine whether these types of educational research matched the methodology adopted by EMU students. In terms of ethical issues, dissertations were coded and analysed anonymously.

\section{Findings and discussion}

The eight types of educational research proposed by Postlethwaite (2005), Norman et al. (2002) and Creswell, 20I2) were identified to verify the methodological consistency of the dissertations defended at EMU from 2013 to 2018 (see Table 2 )
Table 2: Dissertations defended from 2013 to 2018 by code, gender, and type of educational research

\begin{tabular}{|c|c|c|c|c|c|c|c|c|c|c|}
\hline \multirow[t]{2}{*}{ Code } & \multirow[t]{2}{*}{$\begin{array}{l}\text { Area } \\
\text { of } \\
\text { study }\end{array}$} & \multirow[t]{2}{*}{ Year } & \multicolumn{2}{|c|}{ Gender } & \multicolumn{2}{|c|}{$\begin{array}{l}\text { Supervisor } \\
\text { (area of study) }\end{array}$} & \multicolumn{2}{|l|}{$\begin{array}{l}\text { Co-supervisor } \\
\text { (area of study) }\end{array}$} & \multirow{2}{*}{\begin{tabular}{|l|}
$\begin{array}{l}\text { Type of } \\
\text { educational } \\
\text { research } \\
\text { adopted by } \\
\text { the students }\end{array}$ \\
\\
\end{tabular}} & \multirow{2}{*}{$\begin{array}{l}\text { Type of } \\
\text { educational } \\
\text { research } \\
\text { as per } \\
\text { Postlethwaite } \\
(2005), \\
\text { Norman et } \\
\text { al. (2002), } \\
\text { and Creswell } \\
(2012)\end{array}$} \\
\hline & & & Male & Female & Male & Female & Male & Female & & \\
\hline Dissertation 01 & ENSM & 2013 & - & & $\begin{array}{l}\text { PhD in } \\
\text { Education } \\
\text { (Quality } \\
\text { Assurance) }\end{array}$ & & & & $\begin{array}{l}\text { Mixed } \\
\text { methods }\end{array}$ & $\begin{array}{l}\text { Descriptive } \\
\text { study }\end{array}$ \\
\hline $\begin{array}{l}\text { Dissertation } \\
\mathrm{O}^{2}\end{array}$ & $\mathrm{AE}$ & 2013 & - & & $\begin{array}{l}\text { PhD in } \\
\text { History of } \\
\text { Education }\end{array}$ & & $\begin{array}{l}\text { PhD in Adult } \\
\text { Education }\end{array}$ & & Case study & $\begin{array}{l}\text { Descriptive } \\
\text { study }\end{array}$ \\
\hline Dissertation 03 & EAM & 2013 & - & & $\begin{array}{l}\text { PhD in } \\
\text { Physics }\end{array}$ & & $\mathrm{PhD}$ in EAM & & $\begin{array}{l}\text { Descriptive } \\
\text { study }\end{array}$ & Case study \\
\hline $\begin{array}{l}\text { Dissertation } \\
\text { O4 }\end{array}$ & CID & 2013 & - & & $\begin{array}{l}\text { PhD in } \\
\text { Educational } \\
\text { Technology }\end{array}$ & & & $\begin{array}{l}\text { PhD in } \\
\text { Educational } \\
\text { Technology }\end{array}$ & Case study & Case study \\
\hline Dissertation 05 & CID & 2013 & - & & $\begin{array}{l}\text { PhD in } \\
\text { Sociology of } \\
\text { Education }\end{array}$ & & & & Case study & Case study \\
\hline $\begin{array}{l}\text { Dissertation } \\
06\end{array}$ & EAM & 2013 & - & & $\begin{array}{l}\text { PhD in } \\
\text { Philosophy } \\
\text { of Education }\end{array}$ & & & & Case study & $\begin{array}{l}\text { (Multiple) } \\
\text { Case study }\end{array}$ \\
\hline Dissertation 07 & ENSM & 2014 & - & & & $\begin{array}{l}\text { PhD in } \\
\text { ENSM }\end{array}$ & & & $\begin{array}{l}\text { Mixed } \\
\text { methods }\end{array}$ & Case study \\
\hline $\begin{array}{l}\text { Dissertation } \\
08\end{array}$ & EAM & 2014 & & - & $\mathrm{PhD}$ in EAM & & & & $\begin{array}{l}\text { Mixed } \\
\text { methods }\end{array}$ & $\begin{array}{l}\text { Descriptive } \\
\text { study }\end{array}$ \\
\hline $\begin{array}{l}\text { Dissertation } \\
09\end{array}$ & EAM & 2014 & - & & $\begin{array}{l}\text { PhD in } \\
\text { Physics }\end{array}$ & & & & Case study & $\begin{array}{l}\text { (Multiple) } \\
\text { Case study }\end{array}$ \\
\hline Dissertation 10 & EAM & 2014 & - & & $\begin{array}{l}\text { PhD in } \\
\text { Physics }\end{array}$ & & & & $\begin{array}{l}\text { Descriptive } \\
\text { study }\end{array}$ & Co-relational \\
\hline ו1 Dissertation & $\mathrm{AE}$ & 2014 & & • & $\begin{array}{l}\text { PhD in } \\
\text { Psychology }\end{array}$ & & & $\begin{array}{l}\text { PhD in } \\
\text { Psychology }\end{array}$ & Quantitative & Causal study \\
\hline Dissertation 12 & EAM & 2015 & & - & $\mathrm{PhD}$ in EAM & & & & $\begin{array}{l}\text { Mixed } \\
\text { methods }\end{array}$ & Case study \\
\hline Dissertation 13 & CID & 2015 & & - & & $\begin{array}{l}\text { PhD in } \\
\text { ENSM }\end{array}$ & & & $\begin{array}{l}\text { Mixed } \\
\text { methods }\end{array}$ & Co-relational \\
\hline Dissertation 14 & EAM & 2015 & - & & \begin{tabular}{|l|} 
PhD in \\
Linguistics
\end{tabular} & & & & \begin{tabular}{|l|} 
Mixed \\
methods
\end{tabular} & Co-relational \\
\hline Dissertation 15 & AE & 2015 & & - & $\begin{array}{l}\text { PhD in } \\
\text { History of } \\
\text { Education }\end{array}$ & & $\mathrm{PhD}$ in $\mathrm{AE}$ & & Case study & $\begin{array}{l}\text { (Multiple) } \\
\text { Case study }\end{array}$ \\
\hline Dissertation 16 & AE & 2015 & & - & & \begin{tabular}{|l|}
$\mathrm{PhD}$ in \\
Psychology
\end{tabular} & & \begin{tabular}{|l|} 
PhD in \\
Psychology
\end{tabular} & $\begin{array}{l}\text { Descriptive } \\
\text { study }\end{array}$ & $\begin{array}{l}\text { Descriptive } \\
\text { study }\end{array}$ \\
\hline Dissertation 17 & $\mathrm{AE}$ & 2015 & & - & $\begin{array}{l}\text { PhD in } \\
\text { Psychology }\end{array}$ & & $\begin{array}{l}\text { PhD in } \\
\text { Psychology }\end{array}$ & & $\begin{array}{l}\text { Descriptive } \\
\text { study }\end{array}$ & Causal study \\
\hline Dissertation 18 & CID & 2015 & - & & $\begin{array}{l}\text { PhD in } \\
\text { Physics }\end{array}$ & & $\mathrm{PhD}$ in CID & & Quantitative & Co-relational \\
\hline Dissertation 19 & $\mathrm{AE}$ & 2015 & & $\cdot$ & $\mathrm{PhD}$ in $\mathrm{AE}$ & & & & Case study & Case study \\
\hline $\begin{array}{l}\text { Dissertation } \\
20\end{array}$ & EAM & 2015 & & . & & $\begin{array}{l}\text { PhD in } \\
\text { Sociology }\end{array}$ & $\mathrm{PhD}$ in EAM & & Case study & Causal study \\
\hline
\end{tabular}




\begin{tabular}{|c|c|c|c|c|c|c|c|c|c|c|}
\hline \multirow[t]{2}{*}{ Code } & \multirow{2}{*}{$\begin{array}{l}\text { Area } \\
\text { of } \\
\text { study }\end{array}$} & \multirow[t]{2}{*}{ Year } & \multicolumn{2}{|c|}{ Gender } & \multicolumn{2}{|c|}{$\begin{array}{l}\text { Supervisor } \\
\text { (area of study) }\end{array}$} & \multicolumn{2}{|c|}{$\begin{array}{l}\text { Co-supervisor } \\
\text { (area of study) }\end{array}$} & \multirow{2}{*}{$\begin{array}{l}\text { Type of } \\
\text { educational } \\
\text { research } \\
\text { adopted by } \\
\text { the students }\end{array}$} & \multirow{2}{*}{$\begin{array}{l}\text { Type of } \\
\text { educational } \\
\text { research } \\
\text { as per } \\
\text { Postlethwaite } \\
\text { (2005), } \\
\text { Norman et } \\
\text { al. (2002), } \\
\text { and Creswell } \\
\text { (2012) }\end{array}$} \\
\hline & & & Male & Female & Male & Female & Male & Female & & \\
\hline Dissertation 21 & ENSM & 2015 & - & & $\begin{array}{l}\text { PhD in } \\
\text { Physics }\end{array}$ & & & & $\begin{array}{l}\text { Mixed } \\
\text { methods }\end{array}$ & $\begin{array}{l}\text { Descriptive } \\
\text { study }\end{array}$ \\
\hline Dissertation 22 & EAM & 2016 & & - & $\begin{array}{l}\text { PhD in } \\
\text { Sociology of } \\
\text { Education }\end{array}$ & & $\begin{array}{l}\text { PhD in } \\
\text { Sociology of } \\
\text { Education } \\
\end{array}$ & & Case study & $\begin{array}{l}\text { (Multiple) } \\
\text { Case study }\end{array}$ \\
\hline Dissertation 23 & EAM & 2016 & - & & $\begin{array}{l}\text { PhD in } \\
\text { Physics }\end{array}$ & & & & Case study & $\begin{array}{l}\text { Descriptive } \\
\text { study }\end{array}$ \\
\hline Dissertation 24 & CID & 2016 & & - & $\mathrm{PhD}$ in CID & $\begin{array}{l}\mathrm{PhD} \text { in } \\
\mathrm{CID}\end{array}$ & & & Qualitative & $\begin{array}{l}\text { Descriptive } \\
\text { study }\end{array}$ \\
\hline Dissertation 25 & $A E$ & 2016 & & - & & \begin{tabular}{|l|}
$\mathrm{PhD}$ in \\
Sociology
\end{tabular} & & $\mathrm{PhD}$ in $\mathrm{AE}$ & $\begin{array}{l}\text { Bibliographic } \\
\text { research }\end{array}$ & Case study \\
\hline Dissertation 26 & CID & 2016 & - & & & $\begin{array}{l}\text { PhD in } \\
\text { ENSM }\end{array}$ & & & $\begin{array}{l}\text { Bibliographic } \\
\text { research }\end{array}$ & $\begin{array}{l}\text { Descriptive } \\
\text { study }\end{array}$ \\
\hline Dissertation 27 & $A E$ & 2016 & - & & & \begin{tabular}{|l} 
PhD in \\
Psychology
\end{tabular} & & \begin{tabular}{|l} 
PhD in \\
Psychology
\end{tabular} & \begin{tabular}{|l} 
Ex-post \\
facto \\
research
\end{tabular} & $\begin{array}{l}\text { Ethnographic } \\
\text { research }\end{array}$ \\
\hline Dissertation 28 & CID & 2016 & - & & & $\begin{array}{l}\mathrm{PhD} \text { in } \\
\mathrm{CID}\end{array}$ & $\mathrm{PhD}$ in CID & & $\begin{array}{l}\text { Mixed } \\
\text { methods }\end{array}$ & $\begin{array}{l}\text { Descriptive } \\
\text { study }\end{array}$ \\
\hline Dissertation 29 & $A E$ & 2016 & - & & $\mathrm{PhD}$ in $\mathrm{AE}$ & & & & Qualitative & $\begin{array}{l}\text { Research and } \\
\text { development }\end{array}$ \\
\hline Dissertation 30 & CID & 2016 & - & & & $\begin{array}{l}\mathrm{PhD} \text { in } \\
\mathrm{CID}\end{array}$ & & & Exploratory & $\begin{array}{l}\text { Descriptive } \\
\text { study }\end{array}$ \\
\hline Dissertation 31 & AE & 2016 & & - & $\begin{array}{l}\text { PhD in } \\
\text { Education } \\
\text { (Quality } \\
\text { Assurance) }\end{array}$ & $\mathrm{PhD}$ in $\mathrm{AE}$ & & & $\begin{array}{l}\text { Mixed } \\
\text { methods }\end{array}$ & Case study \\
\hline Dissertation 32 & EAM & 2017 & - & & $\begin{array}{l}\text { PhD in } \\
\text { Sociology of } \\
\text { Education }\end{array}$ & & $\begin{array}{l}\text { PhD in } \\
\text { Sociology of } \\
\text { Education }\end{array}$ & & Case study & Case study \\
\hline Dissertation 33 & EAM & 2018 & - & & $\begin{array}{l}\text { PhD in } \\
\text { Education }\end{array}$ & & $\mathrm{PhD}$ in EAM & & $\begin{array}{l}\text { Descriptive } \\
\text { study }\end{array}$ & $\begin{array}{l}\text { Descriptive } \\
\text { study }\end{array}$ \\
\hline
\end{tabular}

EAM: Educational Administration and Management.

ENSM: Education in Natural Sciences and Mathematics.

AE: Adult Education.

CID: Curriculum and Instructional Development.

Source: EMU Open Institutional Repository
Table 2 above lists the 33 dissertations by code, year, gender, area of study, supervisor, and type of educational research. Within this sample, I8 dissertations were supervised and/or co-supervised by specialists, i.e., by supervisors whose training areas are related to students' degree programme areas. Of these, only four are methodologically consistent. On the other hand, despite the fact that the remaining I5 dissertations were supervised by non-specialists, five of these are methodologically consistent. These findings suggest that, being a specialist is an important but not sufficient condition for adequate supervision. This implies the need for on-going training of supervisors on educational research methodology, whether or not they are specialists.

Historical research generates descriptions and sometimes explanations of conditions, situations, and events that occurred in the past, because "time passes between the beginning of the experiment and the end, and events may occur between the pretest and post-test that influence the outcome" (Creswell, 20I2, p. 304). To assess the methodological consistency of historical research, one should ascertain if preliminary research took place, and whether the topic or research question has been identified and refined. There is also a need to ensure the adequacy of the methods and data sources, to enable the use of research evidence to support or reject a hypothesis. Based on this, the researcher is expected to formulate a thesis statement, analyse the data and develop a narrative exposition of the findings.

We did not identify any historical research in the sample. There are two possible reasons: students may have privileged other interests rather than seeking to understand educational events that have already occurred; or they didn't feel methodologically prepared to undertake historical research.

Descriptive research provides information on current conditions, situations, and events. Based on "descriptive statistics, means, standard deviations, and the range of scores to show useful information about results" (Creswell, 20I2, p. I97), its consistency is assessed by determining the degree to which cases that share a given condition or combination of conditions produce the same outcome. However, "descriptive studies lack the powerful controls needed to establish credible links between exposures and outcomes" (Norman et al., 2002, p. 58). For this reason, many researchers that seek to establish possible links between the variables do not consider a simple descriptive study sufficient and therefore focus on co-relational or causal linkages. We identified II dissertations written employing descriptive analysis (Table 2). This number is reasonable given that the descriptive research design is the second most common methodological option, suggesting that this is the methodological procedure students feel most comfortable with, or that their supervisors direct them to this type of educational research. 
Correlational research involves the search for relationships between variables through the use of measures of statistical association. Co-relational designs enable researchers to predict scores and explain the relationships among the variables under study. Such researchers "use the correlation statistical test to describe and measure the degree of association (or relationship) between two or more variables or sets of scores" (Creswell, 2012, p. 338). To assess the consistency of co-relational research, one might check whether participants' scores in the brief test strongly correlate with their scores in the longer one. This is important considering that neither test score is thought to cause the other and there is thus no independent variable to manipulate. Thus, having fulfilled all the relevant steps, the researcher is expected to ensure that the terms independent and dependent variables do not apply to this type of research. We registered four co-relational studies where the variables are associated to verify possible trends. This is an eighth of the total, suggesting that there is little preference for this type of educational research, or that students feel underprepared to undertake it.

Causal research suggests plausible causal linkages between variables. It establishes the underlying causes of events, i.e., the reasons why a particular phenomenon occurred in the way it did and when it did (Norman et al., 2002). Three causal research studies were identified. The consistency of causal research is assessed considering several paths to the same outcome. In this context, consistency assesses the degree to which instances of an outcome agree in displaying the causal condition thought to be necessary, but not sufficient, whereas coverage assesses the relevance of the causal condition. Thus, adding the four co-relational studies to the three causal ones, seven dissertations, or a fifth $(20 \%)$ of the total, aimed to establish associations between the variables under study.

In experimental research, variables defining one or more 'causes' are systematically manipulated to discern their 'effects' on other variables. An example is an experimental study in which the "experiment yields useful information about educational outcomes, but the additional collection of qualitative data develops a more in-depth understanding of how the experimental intervention on it worked" (Creswell, 20I2, p. 535). The consistency of experimental research is assessed by ascertaining the degree to which a measurement supplies reliable results with equal values. It measures the precision, repeatability, and trustworthiness of research and indicates the extent to which it is free from bias, and hence ensures consistent measurement across time and the various items in the instruments. We did not identify any experimental research in this study. It is possible that the differentiated conception of educational sciences, in comparison to others, such as biomedical sciences, may be why students do not adopt experimental research to understand phenomena within the educational sciences.
However, such a conception weakens educational research, because it loses sight of the need to think more in terms of practical application, pragmatic consequences, and outcomes.

The case study is a research design that is "a variation of ethnography in that the researcher provides an in-depth exploration of a bounded system, based on extensive data collection" (Creswell, 20I2, p. 6I7). To assess the methodological consistency of case study research, whether the researcher is an outsider or insider, the issues one should pay attention to for valid data, procedures, and results are: (i) investigating a contemporary phenomenon within its real-life context; (ii) when the boundaries between phenomenon and context are not evident; and (iii) in which multiple sources of evidence are used. When necessary, "case studies can include, and even be limited to, quantitative evidence" (Norman et al., 2002, p. 67). Thirteen dissertations are case studies, constituting the majority of the sample. Because case studies focus attention on certain entities, taken as unities, they seem to be easy. However, this is a misleading, because case studies are also highly demanding.

Ethnographic research consists of a description of events that occur within the life of a group - individuals' interaction in the context of the socio-cultural norms, rituals, and beliefs shared by the group. The consistency of ethnographic research is assessed by ascertaining if, beyond the procedures, data are internally consistent when the researcher records behaviours that are consistent over time and in different social contexts (Sangasubana, 20II). This qualitative procedure describes, analyses, and interprets a cultural group's shared patterns of behaviour, beliefs, and language that develop over time. We identified one ethnographic research study, which may point to weak appropriation of anthropological issues.

Research and development focuses on the interaction between research and the production and evaluation of a new product (Postlethwaite, 2005). The consistency of this research is assessed through a rigorous, valid, and credible examination of the quality of proposed solutions, which have the potential to contribute significantly to the improvement of practices and outcomes of the primary process that is the focus of the research. With one dissertation identified, this type of research is related to the production, testing, and presentation of new products or services.

In summary, of the 33 dissertations in the sample, nine were mixed methods; II case studies; five descriptive studies; two quantitative, qualitative and bibliographic research studies, respectively, and one ex-post facto research, and exploratory study, respectively. According to Postlethwaite (2005), Norman et al. (2002), and Creswell (2012) only case studies and descriptive studies can be considered valid types of educational research. In terms of this typology, mixed methods, quantitative, qualitative, bibliographic, ex-post-facto, and exploratory research are not types of educational 
research but are instead, kinds of educational research. Based on these findings, and due to the misleading research design adopted in the majority of the dissertations, the theories the students claim to confirm are falsified. The theoretical implications of these findings are the need to design educational research in such a way that the procedures deliver the most correct results, recommending appropriate action for school improvement. The practical implications are the need for specialists in educational research to identify strengths and weaknesses and design specific interventions for improvement at EMU.

Data for four of the studies (dissertations 6, 9, I5, and 22) were collected from more than one school and students considered them "multiple case studies". It is important to distinguish between a simple case study and a multiple one. As noted by Gustafsson (20I7, p. II), "with a multiple case study ... the researcher can analyze the data within each situation and across different situations". It thus enables the researcher to understand the similarities and differences between the cases, and generate strong, reliable evidence to clarify if the findings are valuable. The misleading classification of case studies denotes methodological limitations when students design their research projects. Furthermore, we identified a significant number of "mixed methods studies", suggesting that many students feel comfortable conducting quantitative and qualitative research at the same time, based on the idea that mixed methods research provides better results than a single approach.

As shown in Table 2, 20 dissertations were by male and I 3 by female students. There were 13 case studies, II descriptive studies, four co-relational studies, three causal studies, and one ethnographic and research and development study, respectively.

Improved completion rates are pursued by research-focused academics because they one of the measures of research excellence in some countries. However, we did not identify any systematic study at EMU on educational research methods, resulting in a scarcity of "research findings upon which sound evaluation strategies might be grounded" (Seymour et al., 2004, p. 493). A possible reason might be the lack of a theoretical framework in terms of which to assess educational research.

As research and the development of research skills are both a product and a process at university, this should involve students learning how to research within a specific discipline: "research-orientated teaching" (Ali and Abbas, 2019); it should also involve students conducting their research: "research-based teaching" (Rosenshine, 20I2). This is not surprising considering that postgraduate education has been historically linked with academics' research agenda (Jepsen and Varhegyi, 20I2).

Motivated by the desire to break out of the tired old teaching versus research debate, a recent conceptualisation of scholarship suggests possi- bilities other than the seemingly entrenched 'truth' of research and teaching as necessarily competing endeavours (Kyvic, 20I5). Thus, teaching and research may not be in opposition but linked (Robles, 20I6), corresponding with Zieger and Pulichino's vision of "Establishing a Community of Learners" (2004, p. I).

Table 3 describes the typology used to determine whether or not a particular dissertation "matched" the typology proposed by Postlethwaite (2005), Norman et al. (2002), and Creswell (20I2).

Table 3: Typology of Educational Research used by the authors and students

\begin{tabular}{|c|c|c|c|c|c|}
\hline \multicolumn{3}{|c|}{$\begin{array}{l}\text { Types of Educational Research used by the } \\
\text { authors as their typology }\end{array}$} & \multicolumn{3}{|c|}{ Types of Educational Research used by students } \\
\hline Type & $\mathrm{N}$ & $\%$ & Type & $\mathrm{N}$ & $\%$ \\
\hline Historical Research & 0 & 0.0 & - & $\mathrm{o}$ & 0.0 \\
\hline \multirow[t]{6}{*}{ Descriptive Research } & \multirow[t]{6}{*}{11} & \multirow[t]{6}{*}{33.5} & Descriptive Research & 2 & 6.0 \\
\hline & & & Case Study & 2 & 6.0 \\
\hline & & & Mixed Methods & 4 & 12.1 \\
\hline & & & Qualitative Study & 1 & 3.0 \\
\hline & & & Bibliographic Research & 1 & 3.0 \\
\hline & & & Exploratory Study & 1 & 3.0 \\
\hline \multirow[t]{3}{*}{ Co-relational Research } & \multirow[t]{3}{*}{4} & \multirow[t]{3}{*}{12.1} & Descriptive Research & 1 & 3.0 \\
\hline & & & Mixed Methods & 2 & 6.0 \\
\hline & & & Quantitative Research & 1 & 3.0 \\
\hline \multirow[t]{3}{*}{ Causal Research } & \multirow[t]{3}{*}{3} & \multirow[t]{3}{*}{9.0} & Case Study & 1 & 3.0 \\
\hline & & & Quantitative Study & 1 & 3.0 \\
\hline & & & Descriptive Study & 1 & 3.0 \\
\hline Experimental Research & $\circ$ & 0.0 & - & o & 0.0 \\
\hline \multirow[t]{4}{*}{ Case Study } & \multirow[t]{4}{*}{13} & \multirow[t]{4}{*}{39.4} & Case Study & 8 & 24.2 \\
\hline & & & Mixed Methods & 3 & 9.7 \\
\hline & & & Descriptive Research & 1 & 3.0 \\
\hline & & & Bibliographic Research & 1 & 3.0 \\
\hline Ethnographic Research & 1 & 3.0 & Ex-post facto research & 1 & 3.0 \\
\hline Research and Development & 1 & 3.0 & Quantitative Study & 1 & 3.0 \\
\hline Total & 33 & 100.0 & Total & 33 & 100.0 \\
\hline
\end{tabular}

Table 3, shows that Io dissertations (i.e., two descriptive studies and eight case studies), match the typology of educational research used by the authors. Together, they represent $30 \%$ of the 33 dissertations. The remaining 23 dissertations (representing 70\%) do not match the typology used by Postlethwaite (2005), Norman et al. (2002), and Creswell (20I2). 
Table 4: Dissertations defended from 2013 to 2018 by area, supervisors' specialisation, types of educational research, and methodological consistency

\begin{tabular}{|c|c|c|c|c|c|c|c|}
\hline $\begin{array}{l}\text { Disser- } \\
\text { tation }\end{array}$ & Year & $\begin{array}{l}\text { Area of } \\
\text { study }\end{array} \mid$ & Supervisor & Co-supervisor & \begin{tabular}{|l|} 
Type of \\
educational \\
research used by \\
students
\end{tabular} & $\begin{array}{l}\text { Type of educational } \\
\text { research used by the } \\
\text { authors }\end{array}$ & Consistency \\
\hline 03 & 2013 & EAM & Non-specialist & Specialist & Descriptive study & Case study & \\
\hline 06 & 2013 & EAM & Specialist & - & Case study & (Multiple) Case study & Consistent \\
\hline 08 & 2014 & EAM & Specialist & - & Mixed methods & Descriptive study & \\
\hline 09 & 2014 & EAM & Non-specialist & & Case study & (Multiple) Case study & Consistent \\
\hline 10 & 2014 & EAM & Non-specialist & & Descriptive study & Co-relational research & \\
\hline 12 & 2015 & EAM & Specialist & & Mixed methods & Case study & \\
\hline 14 & 2015 & EAM & Non-specialist & & Mixed methods & Co-relational & \\
\hline 20 & 2015 & EAM & Non-specialist & Specialist & Case study & Causal study & \\
\hline 22 & 2016 & EAM & Non-specialist & Non-specialist & Case study & (Multiple) Case study & Consistent \\
\hline 23 & 2016 & EAM & Non-specialist & & Case study & Descriptive study & \\
\hline 32 & 2017 & EAM & Non-specialist & Non-specialist & Case study & Case study & Consistent \\
\hline 33 & 2018 & EAM & Specialist & Specialist & Descriptive study & Descriptive study & Consistent \\
\hline 01 & 2013 & ENSM & Specialist & & Mixed methods & Descriptive study & \\
\hline 07 & 2014 & ENSM & Specialist & - & Mixed methods & Case study & \\
\hline 21 & 2015 & ENSM & Specialist & - & Mixed methods & Descriptive study & \\
\hline 02 & 2013 & $\mathrm{AE}$ & Non-specialist & Specialist & Case study & Descriptive study & \\
\hline 11 & 2014 & $A E$ & Non-specialist & Non-specialist & Quantitative study & Causal study & \\
\hline 15 & 2015 & $\mathrm{AE}$ & Non-specialist & Specialist & Case study & (Multiple) Case study & Consistent \\
\hline 16 & 2015 & $\mathrm{AE}$ & Non-specialist & Non-specialist & Descriptive study & Descriptive study & Consistent \\
\hline 17 & 2015 & $A E$ & Non-specialist & Non-specialist & Descriptive study & Causal study & \\
\hline 19 & 2015 & $A E$ & Specialist & & Case study & Case study & Consistent \\
\hline 25 & 2016 & $A E$ & Non-specialist & Specialist & $\begin{array}{l}\text { Bibliographic } \\
\text { research }\end{array}$ & Case study & \\
\hline 27 & 2016 & $\mathrm{AE}$ & Non-specialist & Non-specialist & $\begin{array}{l}\text { Ex-post-facto } \\
\text { research }\end{array}$ & $\begin{array}{l}\text { Ethnographic } \\
\text { research }\end{array}$ & \\
\hline 29 & 2016 & $A E$ & Specialist & & \begin{tabular}{|l|}
$\begin{array}{l}\text { Quantitative } \\
\text { study }\end{array}$ \\
\end{tabular} & $\begin{array}{l}\text { Research and } \\
\text { development }\end{array}$ & \\
\hline 31 & 2016 & AE & Non-specialist & Specialist & Mixed method & Case study & \\
\hline 04 & 2013 & CID & Non-specialist & Non-specialist & Case study & Case study & Consistent \\
\hline 05 & 2013 & CID & Non-specialist & & Case study & Case study & Consistent \\
\hline 13 & 2015 & CID & Non-specialist & & Mixed method & Co-relational study & \\
\hline 18 & 2015 & CID & Non-specialist & Specialist & $\begin{array}{l}\text { Quantitative } \\
\text { study }\end{array}$ & Co-relational study & \\
\hline 24 & 2016 & CID & Specialist & Specialist & Qualitative study & Descriptive study & \\
\hline 26 & 2016 & CID & Non-specialist & & \begin{tabular}{|l|}
$\begin{array}{l}\text { Bibliographic } \\
\text { research }\end{array}$ \\
\end{tabular} & Descriptive study & \\
\hline 28 & 2016 & CID & Specialist & Specialist & Mixed method & Descriptive study & \\
\hline 30 & 2016 & CID & Specialist & & Exploratory & Descriptive study & \\
\hline
\end{tabular}

EAM: Educational Administration and Management.

ENSM: Education in Natural Sciences and Mathematics.

AE: Adult Education

CID: Curriculum and Instructional Development.
Table 4 above illustrates that ten dissertations were deemed to be methodologically consistent, four of which were supervised by specialists, and six by non-specialists. Eight of the ten dissertations are case studies, and two are descriptive studies. Thus, 23 dissertations were not found to be methodologically consistent, although I4 of these were supervised by specialists. These figures can be synthesised as follows:

I. In the area of Educational Administration and Management (EAM), six of the I2 dissertations were supervised by specialists; and five of the I2 dissertations were deemed methodologically consistent, with three of these supervised by non-specialists.

2. In the area of Education in Natural Science and Mathematics (ENSM), none of the three dissertations are methodologically consistent, although the supervisors are all specialists.

3. In the area of Adult Education (AE), five of the ten dissertations were supervised by specialists, of which three are methodologically consistent. Of these three, two were supervised by specialists.

4. In the area of Curriculum and Instructional Development (CID), two of eight dissertations are methodologically consistent, both of which were supervised by non-specialists. In this area, four dissertations were supervised by specialists.

These figures suggest that EAM has more methodologically consistent dissertations than any other area, due to producing the highest number of dissertations during the period under review.

The fact that 23 dissertations can be considered methodologically inconsistent calls for consideration of the extent to which teaching and research are linked at EMU. Only when the profession embraces scientific methods to determine efficacy and accepts accountability for results will education acquire the status - and the rewards - of a mature profession (Carnine, 2000). Educational researchers are regarded as those who participate in the process of discovery and communication of knowledge (Livingstone, 2005). Universities are, therefore, scholarly communities (Huber and Hutchings, 2004) where the goal is to prepare students for research and practice in their communities. Hickey and Zuiker (2005) state that learning is configured through the process of the learner becoming a full participant in a socio-cultural practice. They add that, "learning involves meaningful participation in the practices that characterize a community" (p. 278). Thorne et al. (2004) cite one of the 'best examples' of the integration of teaching and research as leading to a process of inquiry. Such studies often build upon "relatively small samples, using such data collection methods as interviews, participant observation, and documentary analysis to articulate a coherent and meaningful account of the experiential knowledge" (p. 3). 
According to Haguette (2002), postgraduate studies must familiarise students with epistemological and methodological principles for knowledge generation. If research underlies the centrality of the Master's degree, it is necessary to pay more attention to its theoretical, empirical, and methodological demands. However, "many programs are silent regarding the requirement about the empirical nature of the dissertation, which also requires the theoretical-methodological field exercise" (Haguette, 2002, p. 376).

Wangenge-Ouma et al. (20I5) observe that lecturers at EMU show little commitment to research. They note that, "from a remuneration point of view, it is more lucrative to follow a teaching track than a research career track" (p. I36). Wangenge-Ouma et al. (20I5) add that, less than Ioo of the I 700 academic staff at EMU have chosen the research career track. Hockey (I996) asserts that a good supervisor-student relationship is a key factor in students' success or failure in their studies or research. Therefore, supervision is concerned with the mechanics of ensuring that students are making good progress towards completion.

\section{Conclusion}

There is a need for a strong research-teaching nexus, which refers to the "relationships and interactions that may exist between teaching and research in $\mathrm{HE}$, through curriculum designs and teaching practices" (Covele, 20I7, p. I). The findings of our study show that a large number of Master's in Education dissertations defended at EMU are not methodologically consistent, although some of the results may be useful for reflection on methodological consistency. Thus, these studies do not lay a reliable foundation for future research or interventions for school improvement. The findings reinforce the claim that Mozambican universities "are weak and informal" (Zavale and Macamo, 2016, p. 257).

Zavale (2013) compared the pro-liberal curricula introduced in the $2000 \mathrm{~s}$ in Mozambique with those from the I990s, and identified differences and specificities. He states that the I990s curricula were mainly disciplinary based, insular and rigid, and based on a-social realist epistemology. In contrast, the 2000 s pro-liberal curricula are mainly interdisciplinary, hybrid, flexible, centred on practical/professional knowledge or skills, and inspired by a socio-constructivist epistemology and by claims of socio-economic relevance (Zavale, 20I3).

Empirical evidence on methodological consistency at EMU should be of interest to the entire academic community, researchers, policymakers, and decision-makers. The lack of historical and experimental research noted by this study weakens the methodological options adopted by students. The historical design uses experiences of the past to understand the present and possibly project the future, whereas experimental research is expected to recommend measures to address a specific problem.
Although the results of this research cannot be generalised to the entire university, they suggest that migration from a teaching-centred to a research-based university demands sound theoretical and methodological preparation of researchers, lecturers and students, so that research becomes a practice and an important part of the university's organisational culture. Such migration should not only be an intention but also practice and, therefore, part of the university culture.

\section{Recommendations}

The supervision literature indicates that ethical, technical, and methodological problems can be minimised or prevented if all the participants in the relationship strive to enter it with clear expectations of their respective roles and the rules for their interaction (Goodyear et al., I992). In particular, students require guidance on when to stop data collection and analysis, when to start drafting the dissertation and how to structure it. Therefore, supervisors are expected and assumed to be guides and critical friends (Hockey, I996).

The findings of this study highlight the need for in-depth research to capture and explore perceptions of the types of educational research for future academic interventions. According to Zavale and Langa (20I8), developing countries in Africa suffer from double neglect, not only because they are under-researched, but are also ignored when research on them is produced. Thus, concerns about the quality of training, especially in postgraduate studies, should not only be located within the borders of the university and the country, but also a broader agenda, especially since the modern world is a global village, with professionals moving from one place to another. It is, therefore, possible to take advantage of synergies and different experiences in research capacity building in postgraduate studies between universities located in the country, but also with those of other countries. 


\section{References}

Ali, M. S., and Abbas, Q. (20I9). Research-Oriented Teaching and Students' Academic Performance: Perception of University Teachers. European Online Journal of Natural and Social Sciences 8(I), I-8.

Azarian, R. (20II). Potentials and Limitations of Comparative Method in Social Science. International Journal of Humanities and Social Science I(4), II3-I25.

Brown, J. D. (20I7). Consistency in research design: Categories and subcategories. Shiken 2I(I) 23-28.

Carnine, D. (2000). Why education experts resist effective practices (and what it would take to make education more like medicine). Washington, DC: Fordham Foundation.

Covele, V. J. (20I7). Research-teaching nexus in Mozambican higher education curricula The case study of Eduardo Mondlane University. Unpublished Master's dissertation in Higher Education Studies and Development. Maputo: Eduardo Mondlane University - Faculty of Education.

Creswell, J. W. (20I2). Educational research: planning, conducting, and evaluating quantitative and qualitative research (4th ed.). Boston: Pearson Education.

EMU. (2007). Eduardo Mondlane University Research Policy. Maputo: Scientific Directorate.

EMU. (2013). Postgraduate Curricular Framework. Maputo: Scientific Directorate.

EMU. (20I8). Master's Program in Education. Maputo: MEU - Faculty of Education.

Goodyear, R., Crego, C., and Johnston, M. (I992). Ethical issues in the supervision of student research: a study of critical incidents. Professional Psychology: Research and Practice 23(3), 203-210. https://doi. org/10.1037/0735-7028.23.3.203.

Gustafsson, J. (20I7). Single case studies vs. multiple case studies: a comparative study. Halmstad: Halmstad University.

Haguette, T. M. F. (2002). Metodologias Qualitativas na Sociologia. Petrópolis, RJ: Vozes.

Hammarberg, K., Kirkman, M., and Lacey, S. (20I6). Qualitative research methods: when to use them and how to judge them. Human Reproduction 3I(3), 498-50I. https://doi.org/Io.Io93/humrep/dev334.

Hempenstall, K. (2006). What does evidence-based practice in education mean? Australian Journal of Learning Disabilities II(2), 83-92. https:// doi.org/10.1080/194041506095468II.

Hickey, D. T., and Zuiker, S. J. (2005). Engaged participation: a sociocultural model of motivation with implications for educational assessment. Educational Assessment Io(3), 277-305. https://doi.org/Io.I207/si5326977eaIoo3-7.

Hockey, J. (I996). Strategies and Tactics in the Supervision of UK Social
Science PhD Students. Qualitative Studies in Education 9(4), 48I-500. https://doi.org/Io.1080/0951839960090409.

Holloway, I., and Todres, L. (2005). The status of method: flexibility, consistency and coherence. In: Immy Holloway (ed.) Qualitative Research in Health Care, pp. 90-I03. London: Open University Press.

Huber, M. T., and Hutchings, P. (2004). Integrative learning: mapping the terrain. Washington: Association of American Colleges and Universities. https://files.eric.ed.gov/fulltext/ED486247.pdf.

Jepsen, D. M., and Varhegyi, M. M. (20I2). Awareness, knowledge and intentions for postgraduate study. Journal of Higher Education Policy and Management 3(6), 605-6I7. https://doi.org/10.1080/1360080X.20II.621I87.

Kaweesi, M., Bisaso, R., and Ezati, B. A. (2019). The Nature of and Motive for Academic Research in Higher Education: a sub-Saharan African Perspective. International Journal of African Higher Education 6(I), I-26.

Krefting, L. (I99I). Rigor in Qualitative Research: The Assessment of Trustworthiness. American Journal of Occupational Therapy 45(3), 2I4-222. https://doi.org/IO.50I4/ajot.45.3.2I4.

Kyvic, S. (20I5). The relationship between research and teaching in the humanities. Working Paper 2015:2I. Oslo: Nordic Institute for Studies in Innovation, Research and Education (NIFU).

Langa, P. V. (20I4). Alguns desafios do ensino superior em Moçambique: do conhecimento experiencial à necessidade de produção de conhecimento científico, 365-395. In: de Brito, L., Castel-Branco, C. N., Chichava, S., Forquilha, S., and Francisco, A. (orgs), Desafios para Moçambique 20I4. Maputo: IESE.

Langa, P. V. (20I8). Higher Education as a Field of Research in the Portuguese Speaking Countries: Insights on an Emerging Scientific Field. International Journal of African Higher Education 4(2), 4I-62. https:// doi.org/ıo.6oI7/ijahe.v4i2.ı0296 .

Langa, P. V. and Zavale, C. N. (20I5). Private higher education in Mozambique: an overview of a growing subsystem. Working Papers in Higher Education Studies I(2), 89-Io9.

Livingstone, I. D. (2005). From educational policy issues to specific research questions and the basic elements of research design. Paris: UNESCO/IIEP.

Mário, M., Fry, P., Levey, L., and Chilundo, A. (2003). Higher Education in Mozambique: a case study. Maputo: Imprensa and Livraria Universitaria - Universidade Eduardo Mondlane.

Maynard, B. R., Vaughn, M. G., and Sarteschi, C. M. (20I2). The Empirical Status of Social Work Dissertation Research: Characteristics, Trends and Implications for the Field. British Journal of Social Work (20I4) 44, 267-289. https://doi.org/ıo.I093/bjsw/bcsi23. 
Mohajan, H. K. (20I8). Qualitative Research Methodology in Social Sciences and Related Subjects. Journal of Economic Development, Environment and People 7(OI), 23-48. DOI: Io.26458/jedep.v7iI.57I.

Newman, I., and Covrig, D. M. (2013). Writer's forum - building consistency between title, problem statement, purpose and research questions to improve the quality of research plans and reports. New Horizons in Adult Education and Human Resource Development 25(I), 70-79.

Noble, H., and Smith. J. (2015). Issues of validity and reliability in qualitative research. Evidence Based Nursing I8(2), 34-35. http://dx.doi. org/IO.II36/eb-20I5-IO2054.

Norman, G. R., van der Vleuten, C. P. M., and Newble, D. (2002). International Handbook of Research in Medical Education. German: Springer-Science+Business Media, B.V.

Opoku, A., Ahmed, V., and Akotia, J. (2016). Choosing an appropriate research methodology and method. In: Ahmed, V., Opoku, A., and Aziz, Z. (eds) Research Methodology in Built Environment, pp. 32-49. London and New York: Routledge Francis and Taylor Group.

Postlethwaite, T. N. (2005). Educational Research: Some basic concepts and terminology. Paris: UNESCO/IIEP.

Robles, M. M. (20I6). The Relationship Between Academic Research and Instructional Quality. Association for Business Communication 2016 Annual Conference Proceedings.

Ross, K. N. (2005). Sample design for Educational Research. Paris: UNESCO/IIEP.

Sangasubana, N. (20II). How to Conduct Ethnographic Research. The Qualitative Report I6(2), 567-573.

Seymour, E., Hunter, A., Laursen, S., and Deantoni, T. (2004). Establishing the benefits of research experiences for undergraduates in the sciences: first findings from a three-year study. Science Education 88(4), 493-534. https://doi.org/IO.I002/sce.IOI3I.

Thorne, S., Kirkham, S. R., and O'Flynn-Magee, K. (2004). The Analytic Challenge in Interpretive Description. International Journal of Qualitative Methods 3(I), I-II. https://doi.org/Io.II77/I60940690400300IoI.

Tie, Y. C., Birks, M., and Francis, K. (20I9). Grounded theory research: A design framework for novice researchers. SAGE Open Medicine 7, I-8. https://doi.org/IO.II77/2050312II8822927.

Wangenge-Ouma, G., Lutomiah, A., and Langa, P. V. (20I5). Academic Incentives for Knowledge Production in Africa: Case studies of Mozambique and Kenya. In: Cloete, N., Maassen, P., and Bailey T. (eds) Knowledge production and contradictory functions in African Higher Education, pp. I28-I47. South Africa: African Minds.

Zavale, N. C. (20I3). Using Michael Young's Analysis on Curriculum Studies to Examine the Effects of Neoliberalism on Curricula in Mozambique. Policy Futures in Education II(5), 62I-636. http://dx.doi.org/I0.2304/ pfie.20I3.II.5.62I.

Zavale, N. C., and Langa, P. V. (2018). University-industry linkages' literature on Sub-Saharan Africa: systematic literature review and bibliometric account. Scientometrics II6:I-49. https://doi.org/IO.IO07/ SIIIO2-0I8-2760-4.

Zavale, N. C., and Macamo, E. (20I6). How and what knowledge do universities and academics transfer to industry in African low-income countries? Evidence from the stage of university-industry linkages in Mozambique. International Journal of Educational Development 49, 247-26. http://dx.doi.org/ıo.IoI6/j.ijedudev.20I6.04.00I.

Zieger, L., and Pulichino, J. (2004). Establishing a Community of Learners: a case study of a University Graduate Orientation Program for Online Learners. The Journal of Interactive Online Learning 2(4), I-I3. 